\title{
PORESKA UTAJA
}

\author{
Muamer Nicević, prof. dr \\ Internacionalni - Univerzitet u Novom Pazaru \\ Novi Pazar, Srbija \\ d.prava@uninp.edu.rs
}

\author{
Aleksandar R. Ivanović, MSc \\ Internacionalni - Univerzitet u Novom Pazaru \\ Novi Pazar, Srbija \\ a.ivanovic@uninp.edu.rs
}

\begin{abstract}
Apstrakt
Autori razmatraju i analiziraju krivično delo poreske utaje u skladu sa pravnom regulativom krivičnog zakonodavstva Republike Srbije, ukazujući na osnovne načine izvršenja ovog krivičnog dela.

Na kraju rada posebna pažnja posvećena je davanju osnovnih smernica za unapređenje delatnosti na polju suprotstavljanja ovom vidu kriminalnog ispoljavanja.
\end{abstract}

Ključne reči: porez, utaja poreza, otkrivanje, dokazivanje

\section{TAX EVASION}

\begin{abstract}
The authors analyze and discuss the criminal offence of tax evasion in accordance with legal regulations of the criminal legislation of the Republic of Serbia, pointing to a basic form of execution of this crime.

At the end of the work, special attention is given to providing basic guidelines for the promotion of activities in the field of combating this form of criminal expression.
\end{abstract}

Keywords: tax, tax evasion, detection, proving

JEL Codes: K42

\section{UVOD}

Radi se o krivičnom delu koje se ogleda u delimičnom ili potpunom izbegavanju plaćanja poreza, doprinosa ili drugih propisanih dažbina.

Odgovarajućim zakonskim propisima Republike Srbije utvrđene su vrste poreza i obaveza njihovog plaćanja. S tim u vezi, postoji više vrsta poreza, poput akciza, poreza na dodatu vrednost (PDV), poreza na dobit, poreza na dohodak, poreza na imovinu, poreza na dohodak građana, porez na prihod od međunarodnog saobraćaja, i sl, kao i razni oblici doprinosa. 
Objekt zaštite ovog krivičnog dela jeste fiskalni sistem zemlje. Stoga, se svaka država trudi se da svojim pozitivnim krivičnim zakonodavstvom inkriminiše ovaj oblik društveno negativnog ponašanja. Objekt napada krivičnog dela obuhvata poreze, doprinose ili druge dažbine propisane zakonodavstvom Republike Srbije. Porez predstavlja dažbinu, koju fizička i pravna lica, tj. poreski obveznici uplaćuju državi, lokalnoj zajednici ili drugim javnim institucijama radi pokrića rashoda njihove delatnosti, odnosno u cilju naknade za korišćenje određenih usluga. Porez se utvrđuje zakonom, i kao takav predstavlja osnovni izvor budžeta države. Dakle, radi se o instrumentu javnih prihoda kojim država od subjekta pod njenom poreskom nadležnošću uzima novčana sredstva bez neposredne protivusluge, a u svrhu pokrivanja svojih finansijskih potreba ili postizanja ekonomskih ciljeva. Doprinosi predstavljaju vrstu dažbine, koja se naplaćuje iz prihoda svih zaposlenih osoba i njihovih poslodavaca, a služi za podmirivanje potreba po osnovu penzijskog, zdravstvenog, invalidskog i drugih oblika socijalnog osiguranja zaposlenih osoba i članova njihovih porodica, kao i nezaposlenih osoba.

Priroda i sadržina ovih obaveza određuje se drugim van krivičnim propisima što ovom krivičnom delu daje obeležje blanketnog karaktera. Kao što u krivičnom pravu ne može postojati krivično delo niti kazna bez zakona tako ne može ni da se propisuje porez bez zakona. Sama dispozicija ovog krivičnog dela je blanketne prirode. Da bi se ona primenila potrebno je utvrditi da li je od strane poreskog obveznika bilo povrede poreza i drugih normi iz oblasti fiskalnih i poreskih propisa. Upravo je zbog toga, ranije ovo delo i bilo inkriminacija u Zakonu o poreskom postupku i poreskoj administraciji iz koga je preuzeto, odnosno preneto u Krivični zakonik zakonskim novelama iz 2005 godine. Krivični zakonik propisuje jedan osnovni (stav 1) i dva kvalifikovana oblika ovog krivičnog dela (stav 2. i 3), kod kojih kvalifikatornu okolnost predstavlja iznos obaveza čije plaćanje učinilac izbegava.

\section{POJAVNI OBLICI}

Osnovni oblik krivičnog dela izbegavanja plaćanja poreza odnosno utaje poreza vrši onaj koji u nameri da potpuno ili delimično izbegne plaćanje poreza, doprinosa ili drugih dažbina daje lažne podatke o stečenim prihodima, predmetima i drugim činjenicama koje su u vezi za utvrđivanjem ovakvih obaveza, ili ko u istoj nameri, u slučaju obavezne prijave, ne prijavi zakonito stečene prihode, odnosno predmete ili druge činjenice koje su od uticaja na utvrđivanje ovakvih obaveza ili ko u istoj nameri prikriva podatke koji se odnose na utvrđivanje navedenih obaveza a iznos obaveze čije se plaćanje izbegava prelazi iznos od sto pedeset hiljada dinara (čl. 229 st. 1. KZRS). Za ovaj oblik dela predviđena je kazna zatvora do tri godine i novčana kazna. Radnja izvršenja je alternativno određena, te se osnovni oblik krivičnog dela može učiniti preduzimanjem bilo koje od sledećih delatnosti:

a) davanjem lažnih podataka o stečenim prihodima, predmetima i drugim činjenicama koje su od uticaja za utvrđivanje poreza; 
b) ne prijavljivanjem zakonito stečenih prihoda (u slučaju obavezne prijave), odnosno predmeta i drugih činjenica koje su od uticaja za utvrđivanje poreza;

v) na drugi način prikrivanjem podataka koje se odnose na utvrđivanje poreza, doprinosa i drugih dažbina.

Davanjem lažnih podataka o stečenim prihodima, predmetima i drugim činjenicama koje su od uticaja za utvrđivanje poreza, se vrši tako što učinilac podnosi prijavu na osnovu koje treba da mu se utvrdi plaćanje poreza, ali u tu prijavu unosi neistinite podatke. Podaci će biti neistiniti kada ne odgovaraju objektivnom, pravom činjeničnom stanju u pogledu stečenih prihoda i drugih činjenica koje su od uticaja na utvrđivanje neke konkretne obaveze. Takvim lažnim prikazivanjem činjenica izvršilac dela dovodi u zabludu državni organ u pogledu visine osnovice za utvrđivanje poreza i time i ovom delu daje karakter posebnog oblika prevare [2, str. 618]. Treba imati na umu da se svakim lažnim prijavljivanjem podataka ne vrši ovo krivično delo već je potrebno da taj podatak bude relevantan za utvrđivanje poreskih obaveza i doprinosa. S tim u vezi neće postojati ovo krivično delo ako je poslodavac dao lažan podatak o imenu radnika, međutim ako je dao lažan podatak o stečenim prihodima svakako da je reč o ovo krivičnom delu.

Osim toga za postojanje ovog krivičnog dela nije od značaja na koji način i u kom obliku je podneta poreska prijava. Naime, ona može biti podneta pismeno ili data usmeno na zapisnik, ili naknadnim davanjem podataka na traženje poreskog organa. Pod ovim se podrazumeva i prezentiranje poslovnih knjiga sa lažnim podacima, kao i bilo kog drugo pojedinačnog dokumnta koji sadrži lažan podatak koji je relevantan za utvrđivanje i razrez poreza. Dakle, važno je da su podaci koji se daju lažni, tj. da ne odgovaraju stvarno stečenim prihodima, predmetima, odnosno drugim činjenicama koje su relevantne za utvrđivanje iznosa poreza, doprinosa ili kakvih drugih dažbina [3, str. 914]. Ovde treba napomenuti, da ako se ipak radi o podnošenju poreske prijave sa lažnim podacima, u smislu poreske prijave utvrđenom u članu 38. Zakona o poreskom postupku i poreskoj administraciji ${ }^{1}$, da bi ovaj oblik radnje izvršenja bio potpun, poreska prijava sa lažnim podacima mora biti podneta organu koji je nadležan za utvrđivanje poreza odnosno Poreskoj upravi. Poreski obveznik lažne podatke može dati kako u osnovnoj, tako i u izmenjenoj poreskoj prijavi koja se podnosi u skladu sa članom 40. Zakona o poreskom postupku i poreskoj administraciji. Naime, ukoliko poreski obveznik u prvobitno podnetoj poreskoj prijavi navede tačne podakte, a zatim naknadno, u roku podnetoj izmenjenoj poreskoj prijavi, o istim predmetima oporezivanja, navede lažne podake, takođe će se raditi o ovom obliku krivičnog dela poreske utaje.

Ne prijavljivanjem činjenica koje su od značaja za utvrđivanje poreza u nameri delimičnog ili potpunog izbegavanja plaćanja ovih obaveza, poreski obveznik ne ispunjava obavezu prijavljivanja činjenica za utvrđivanje poreza, jer ne podnosi

\footnotetext{
${ }^{1}$ Prema članu 38. Zakona o poreskom postupku i poreskoj administraciji, poreska prijava predstavlja izveštaj poreskog obveznika Poreskoj upravi o ostvarenim prihodima, izvršenim rashodima, dobiti, imovini, prometu dobara i usluga i drugim transakcijama od značaja za utvrđivanje poreza. Poreska prijava podnosi se na obrascu, koji propisuje ministar, uz koji se prilažu odgovarajući dokazi.
} 
prijavu ili podatak koji služi kao osnov za utvrđivanje poreza, odnosno ne podnosi poresku prijavu u propisanom roku, kada je to zakonom ili podzakonskim aktom izričito propisano. Dakle ovaj oblik dela se može ogledati u izostavljanju, odnosno ne navođenju činjenica koje su bitne za utvrđivanje poreza u poreskoj prijavi ili u nepodnošenju poreske prijave u propisanom roku.

U prvom slučaju za razliku od prethodnog oblika izvršenja ovog krivičnog dela, poreski obveznik ne navodi lažne činjenice, već izostavlja, odnosno uopšte ne navodi činjenice koje su od značaja za utvrđivanje poreza. S tim u vezi, kao i kod prvog oblika i kod ovog oblika izvršenja krivičnog dela utaje poreza, odnosno u slučaju kada se radi o izostavljanju, tj. nepodnošenju činjenica koje su od značaja za utvrđivanje poreza, samo izostavljanje podataka na prijavi ne znači da su ispunjeni uslovi potrebni za postojanje ovog krivičnog dela, već je potrebno da ti podaci budu relevantni u smislu krivično pravnih odredbi.

U drugom slučaju poreski obveznik uopšte ne podnosi poresku prijavu, odnosno propušta da u propisanom roku podnese poresku prijavu. Naime, kao što je to već istaknuto, članom 38. Zakona o poreskom postupku i poreskoj administraciji, poreska prijava predstavlja izveštaj poreskog obveznika Poreskoj upravi o ostvarenim prihodima, izvršenim rashodima, dobiti, imovini, prometu dobara i usluga i drugim transakcijama od značaja za utvrđivanje poreza. Takođe, pomenutim članom je propisano da se poreska prijava se podnosi u roku propisanom poreskim zakonom Poreskoj upravi u mestu u kojem je podneta prijava za registraciju, osim ako je poreskim zakonom drukčije uređeno. Ovde takođe treba napomenuti da je u članu 39. Zakona o poreskom postupku i poreskoj administraciji predviđena mogućnost produženja roka za podnošenje poreske prijave. Naime, Poreska uprava može poreskom obvezniku, na njegov pismeni zahtev, podnet pre isteka roka za podnošenje poreske prijave, da odobri produženje roka podnošenja iz opravdanih razloga (bolest, odsustvovanje iz zemlje, nesrećni slučaj, elementarna nepogoda većih razmera i sl.), dok ti razlozi ne prestanu, a najduže za šest meseci od dana isteka zakonskog roka za podnošenje prijave. O zahtevu za produženje roka za podnošenje poreske prijave rešava zaključkom Poreska uprava u mestu u kojem se podnosi poreska prijava, u roku od pet dana od dana prijema zahteva (član 39 ZPPPA). Ako poreski obveznik i posle produžetka roka, ako je takvog produžetka bilo, ne podnese poresku prijavu, onda se takođe radi o ovom obliku izvršenja krivičnog dela poreske utaje.

Treba napomenuti da se obaveza prijavljivanja prihoda odnosi samo na zakonito stečene prihode jer se nezakonito stečena imovina ne može oporezivati i tako odobravati ono što podleže oduzimanju ili kažnjavanju. Dakle, neće postojati krivično delo utaje poreza, ako se ne prijavljuju prihodi stečeni nekom kriminalnom delatnošću.

Na drugi način prikrivanjem podataka koje se odnose na utvrđivanje poreza, doprinosa i drugih dažbina poreski obveznik prikriva činjenice od značaja za utvrđivanje poreza, doprinosa i drugih dažbina. Radi se o trećem načinu izvršenja osnovnog oblika krivičnog dela poreske utaje, koji obuhvata sve one radnje kojima se prikrivaju podaci koji se odnose na utvrđivanje poreza, doprinosa i drugih dažbina, a koje nisu obuhvaćene radnjama koje se odnose na davanje lažnih podataka o stečenim prihodima, predmetima i drugim činjenicama koje su od uticaja 
za utvrđivanje poreza, odnosno radnjama ne prijavljivanja činjenica koje su od značaja za utvrđivanje poreza, u napred navedenom smislu reči. Ovaj način izvršenja osnovnog oblika krivičnog dela poreske utaje, uglavnom se ogleda u nepravilnom obračunavanju poreskih obaveza, zatim lažnom bilansiranju pojedinih pozicija, vođenjem dvojnog knjigovodstva i sl.

Učinilac ovog krivičnog dela može biti fizičko lice, kao i odgovorno lice u subjektu privrednog poslovanja. Odgovorno lice u subjektu privrednog poslovanja može biti: vlasnik preduzeća, lice kome je s obzirom na njegovu funkciju, uložena sredstva ili na osnovu ovlašćenja poveren određen krug poslova u upravljanju imovinom, proizvodnji ili drugoj delatnosti, odnosno u vršenju nadzora nad njima i sl. (punomoćnici, zakonski zastupnici, osnivači i vlasnici privrednih društava, predsednici upravnog odbora, knjigovođe poreskog obveznika i sl.). U pogledu vinosti za postojanje ovog krivičnog dela potreban je direktan umišljaj (svest i volja o postojanju krivičnog dela). Međutim svi navedeni oblici ovog krivičnog dela su praćeni i jednom subjektivnom okolnošću, a to je namera učinioca da preuzimanjem neke od navedenih radnji delimično ili u potpunosti izbegne plaćanje poreza, a samim tim pribavi i protivpravnu imovinsku korist. Ako nema ovakve namere neće biti ni ovog krivičnog dela već će se raditi o određenom prekršaju ili privrednom prestupu. Dokazivanje ovog krivičnog zahteva utvrđivanje postojanje pomenute namere. Vinost kod ovog krivičnog dela obuhvata svest učinioca o okolnostima kojima se konkretizuje radnja izvršenja krivičnog dela, zatim svest o posledici i svest o uzročnoj vezi između radnje i posledice. Svest o okolnostima kojima se konkretizuje radnja izvršenja krivičnog dela obuhvata samu svest, o radnji izvršenja tj. davanju lažnih podataka o činjenicama koje su od uticaja za utvrđivanje poreza, ne prijavljivanju ili prikrivanju tih činjenica. Svest o posledici kod ovog krivičnog dela ogleda se u svesti da se pomenutim radnjama ide na potpuno ili delimično izbegavanje plaćanja poreza i na prouzrokovanje štete budžetu i određenim fondovima. Svest o uzročnoj vezi, između radnje i posledice ogleda se u svesti učinioca da je njegova radnja izvršenja uzrok posledice, odnosno da će usled ove radnje kojom namerava da potpuno ili delimično izbegne plaćanje poreza prouzrokovati određenu štetu [4, str. 152]. Ako ne bi postojala svest učinioca o ovim okolnostima onda ne bi bilo ni direktnog umišljaja, odnosno namere kao jednog od elemenata bića krivičnog dela pa prema tome ne bi postojalo ni krivično delo.

Delo je izvršeno samim podnošenjem prijava sa lažnim podacima, odnosno u momentu propuštanja roka za prijavu, odnosno prikrivanjem činjenice koje se odnose na utvrđivanje poreza, doprinosa i drugih dažbina. Dakle kod krivičnog dela poreske utaje posledica nastaje u momentu preduzimanja radnje izvršenja ovog krivičnog dela. Kada je u pitanju ovo krivično delo treba reći da je u smislu posledice ono povezano i sa određenim objektivnim uslovom (šteta je uneta kao objektivni uslov). Radi se o krivičnom delu samo ako izvršilac preduzme radnju izvršenja u nameri da izbegne plaćanje poreza u iznosu preko sto pedeset hiljada dinara. U tom smislu za postojanje ovog krivičnog dela nije potrebno da je učinilac i uspeo u svojoj nameri već je potrebno da je u konkretnom slučaju preduzeta radnja izvršenja krivičnog dela.

Drugi oblik ovog krivičnog dela je zapravo kvalifikovani oblik krivičnog dela poreske utaje. Kvalifikatorna okolnost se odnosi na vrednost poreza, doprinosa ili 
drugih dažbina čije se plaćanje izbegava (čl.229. st. 2. KZRS). Ovaj oblik dela postojaće ako iznos poreza, doprinosa ili kakvih drugih dažbina čije se plaćanje izbegava prelazi milion i petsto hiljada dinara. Za ovaj oblik krivičnog dela propisana je kumulativno kazna zatvora od jedne do pet godina i novčana kazna.

Treći oblik oblik je takođe kvalifikovani oblik, i postojaće kada se preduzimanjem radnje osnovnog oblika ovog krivičnog dela izbegava plaćanje poreza, doprinosa ili kakvih drugih dažbina u iznosu koji prelazi sedam miliona i petsto hiljada dinara (čl.229. st. 3. KZRS). Za ovaj oblik dela predviđena je kumulativno kazna zatvora od jedne do osam godina i novčana kazna.

Krivično gonjenje za sva tri oblika krivičnog dela utaje poreza preduzima se isključivo po službenoj dužnosti.

\section{NAČIN IZVRŠENJA}

S obzirom na specifičnost ovog krivičnog dela, kao i na čestu promenu zakonske regulative koja se bavi oporezivanjem fizičkih i pravnih lica, gotovo da je nemoguće obuhvatiti sve načine izvršenja ovog krivičnog dela, stoga ćemo ukazati samo na one najučestalije. Takođe, s obzirom na to da u zavisnosti od vrste poreza čije se plaćanje izbegava postoje znatne razlike u načinu izvršenja krivičnog dela poreske utaje, ukazaćemo samo na najučestalije načine izvršenja s obzirom na vrstu poreza, čije se plaćanje izbegava. Dakle, sasvim je drugačija radnja izvršenja kod izbegavanja plaćanja poreza na dohodak građana od radnje izvršenja kod izbegavanja poreza na dodatu vrednost, mada i unutar izbegavanje tih osnovnih poreskih oblika postoje određene specifičnosti koje uopšte nisu zanemarljive. Naime, još značajnije specifičnosti postoje kod različitih delatnosti pri čijem vršenju se poreska utaja čini, i to u okviru istog poreskog oblika, odnosno vrste poreza. Tako postoje značajne razlike između radnje izvršenja poreske utaje kod, na primer, utaje poreza na dodatu vrednost u građevinskoj delatnosti i poljoprivredi. Stoga je, radi razumevanja razlike u radnjama, odnosno načinima izvršenja poreske utaje kod različitih poreskih formi, nužno te radnje grupisati u određene, uslovno rečeno, osnovne kategorije, odnosno podkategorije [5, str. 97]. Shodno navedenom načine izvršenja krivičnog dela utaje poreza, s obzirom na vrstu poreza čije se plaćanje izbegava, a koji se najčešće ispoljavaju u praksi možemo podeliti na:

- utaju poreza na dohodak građana;

- utaju poreza na dobit preduzeća;

- utaju godišnjeg poreza na dohodak građana;

- utaju poreza na dodatu vrednost;

- utaju akciza.

Utaja poreza na dohodak građana predstavlja način izvršenja krivičnog dela poreske utaje koji se ogleda u izbegavanju plaćanja propisani poreza i doprinosa prilikom isplata zarada, odnosno svih oblika isplata koje u skladu sa Zakonom o porezu na dohodak građana imaju tretman zarada. ${ }^{2}$

\footnotetext{
${ }^{2}$ Pod zaradom u smislu ovog zakona, smatra se zarada koja se ostvaruje po osnovu radnog odnosa, definisana zakonom kojim se uređuju radni odnosi i druga primanja zaposlenog. Zaradom, u smislu ovog zakona, smatraju se i ugovorena naknada i druga primanja koja se
} 
Radi se o raznovrsnim oblicima isplata koje se vrše u gotovom novcu, počev od plata zaposlenima i povremenim radnicima, kao i naknada vlasnicima i osnivačima preduzeća, do isplata naknada za izvršene usluge i isporučena dobra koja se ne evidentiraju u poslovnim knjigama. S obzirom da je obim ovakvih plaćanja gotovim novcem veliki, postoji velika potražnja za gotovim novcem na ilegalnom tržištu. Ta potražnja se podmiruje preko širokog spektra nezakonitih transakcija koje imaju za cilj ,izvlačenje“ gotovog novca iz legalnih tokova bez plaćanja propisanih poreskih obaveza [5, str. 100-101].

Dakle ovaj način izvršenja krivičnog dela utaje poreza se ogleda u tome što se vrši i izbegavanje plaćanja obaveza po osnovu poreza na dohodak građana, na način što se zarade ne isplaćuju preko žiro računa, već u gotovom novcu, naturi, odnosno robi i sl. Naime, zarade, osnovno plate zaposlenih se prikazuju kao da su obračunate po najnižoj osnovici, i na taj iznos obračunavaju se i uplaćuju porez i doprinosi na lična primanja. U stvarnosti radi se o znatno većim iznosima, čija se razlika isplaćuje u gotovom novcu, te se na taj način izbegava plaćanje poreza i doprinosa na ovako isplaćenu razliku. Pored navedenog metoda izbegavanja plaćanja poreza i doprinosa na lična primanja, u praksi je veoma čest slučaj izbegavanja plaćanja pomenutih dažbina koji se vrši ne prijavljivanjem radnika. Zatim ovaj način izvršenja se ogleda u vršenju isplate iz blagajne preduzeće bez odgovarajuće knjigovodstvene evidencije ličnog primanja i bez obračuna i plaćanja poreza i doprinosa na zaradu, a naročito kada je ona učinjena radi namirenja ličnih potreba zaposlenog, odgovornog lica, vlasnika, osnivača ili trećih lica van privrednog društva na čiji se teret isplata vrši. Jedan od način izvršenja ovog oblika utaje poreza jeste podizanje gotovog novca od strane poreskih obveznika (pravnih lica) sa svojih tekućih računa pri čemu lažno prikazuju različite osnove takvog podizanja koji ne podrazumevaju obavezu plaćanja poreza na ostale prihode. Tako se, pri podizanju gotovog novca često prikazuje da se to čini radi otkupa poljoprivrednih proizvoda, sekundarnih sirovina i slično, a u realnosti se podignuti novac koristi za u potpuno druge svrhe, a uglavnom za lične potrebe vlasnika preduzeća sa čijeg se tekućeg računa gotov novac podiže. Još jedan od načina izvršenja ovog krivičnog dela ogleda se u ne prijavljivanju prihoda koja fizička ili pravna lica ostvaruju izdavanjem stanova, poslovnih i drugih prostorija u zakup. Privredna društva vrše ovo krivično delo prikrivanjem proizvedene i prodate robe, kao i neiskazivanjem stvarnog obima izvršenih usluga. Naime odgovorna lica u privrednim subjektima koji se bave prodajom različitih vrsta krajnjim konzumentima ili pružanjem određenih vrsta usluga, isporučenu robu, odnosno pružene usluge, naplaćuju u gotovom novcu bez evidentiranja u poslovnim knjigama. Gotov novac zatim zadržavaju za sebe, odnosno koriste za lične potreba ili predaju vlasnicima tih privrednih subjekata koji ih potom koriste za svoje lične

ostvaruju obavljanjem privremenih i povremenih poslova na osnovu ugovora zaključenog neposredno sa poslodavcem, kao i na osnovu ugovora zaključenog preko omladinske ili studentske zadruge, osim sa licem do navršenih 26 godina života, ako je na školovanju u ustanovama srednjeg, višeg i visokog obrazovanja (član 13 ZOPDHG). Zaradom u smislu ovog zakona smatraju se i primanja u obliku bonova, novčanih potvrda, akcija, osim akcija stečenih u postupku svojinske transformacije, ili robe, činjenjem ili pružanjem pogodnosti, opraštanjem duga, kao i pokrivanjem rashoda obveznika novčanom nadoknadom ili neposrednim plaćanjem (član 13 ZOPDHG). 
potrebe. Nije redak slučaj da se ovako dobijenim gotovim novcem vrše gotovinske isplate zarada i drugih primanja zaposlenih ili čine kakva plaćanja prema trećim licima. Jedan od pojavnih oblika ovog krivičnog dela ogleda se u otvaranju privatnih firmi, radnji, agencija i drugih oblika poslovanja bez prijavljivanja takve delatnosti nadležnom državnom organu, tačnije Agenciji za privredne registre.

U građevinarstvu je naročito rasprostranjen ovaj oblik utaje poreza, pre svega zbog velikih mogućnosti za nesmetano realizovanje ovog vida kriminalnog ispoljavanja u ovoj grani privrednog poslovanja. Naime, u oblasti građevinarstva, česti su slučajevi utaje poreza od strane privrednih društava koji se bave projektovanjem, na taj način što se usluge projektovanja fizičkim licima ne evidentiraju kroz poslovne knjige, već se takve usluge naplaćuju u gotovom novcu. Na ovaj način u praksi se protivpravno pribavlja protivpravna imovinska korist u ogromnim iznosima i time nanosi velika šteta državnom budžetu. Osim ovog načina jedan od čestih načina utaje poreza u oblasti građevinarstva ogleda se u prikazivanju manje cene kvadratnog metra od cene po kojoj je stambeni, odnosno poslovni prostor stvarno prodat.

Utaja poreza na dobit preduzeća predstavlja način izvršenja krivičnog dela poreske utaje koji se ogleda u izbegavanju plaćanja propisani poreza i doprinosa putem uvećanja rashoda ili umanjenja prihoda preduzeća. Dakle, izbegavanje plaćanja poreza na dobit preduzeća se ostvaruje na dva načina: uvećanjem rashoda i umanjenjem prihoda.

Uvećanje rashoda u cilju utaje poreza na dobit preduzeća se ogleda u smanjenju osnovice poreza na dobit, čime se umanjuje oporeziva dobit. Ovo se vrši tako što se lažno uvećavaju rashodi preduzeća fiktivnim uvećanjem troškova poslovanja, otvaranjem lažnih bilansnih pozicija, falsifikovanjem faktura i sl. Rashodi preduzeća se lažno uvećavaju po osnovu lažnih računa, odnosno faktura prikazuju troškovi, izdaci i sl., koji se prema Međunarodnim računovodstvenim standardima i propisima o računovodstvu i odgovarajućim odredbama Zakona o porezu na dobit preduzeća mogu priznati kao rashodi preduzeća, čime se povećava iznos rashoda u bilansu uspeha preduzeća. Radi se o rashodima koji su uknjiženi, a koji realno nisu nastali.

Umanjenje prihoda u cilju utaje poreza na dobit preduzeća se ogleda u netačnom prikazivanju prihoda preduzeća. Naime, za utvrđivanje oporezive dobiti preduzeća, najpre je neophodno da preduzeće u bilansu uspeha tačno iskaže podatke o svojim prihodima u skladu sa Međunarodnim računovodstvenim standardima i propisima o računovodstvu i odgovarajućim odredbama Zakona o porezu na dobit preduzeća. Radi se o jednom od najučestalijih načina izbegavanja plaćanja poreza koji se ogleda u prikazivanju ukupnog prihoda u manjem iznosu od stvarno ostvarenog, što se uglavnom vrši neprikazivanjem svih ostvarenih prihoda i sl. Kod utaja poreza od strane pravnih lica, na ovaj način karakteristično je to da se uglavnom vodi duplo knjigovodstvo, jedno za potrebe kontrolnih organa a drugo za potrebe samih poreskih obveznika.

Utaja godišnjeg poreza na dohodak građana predstavlja način izvršenja krivičnog dela poreske utaje koji se ogleda u nepodnošenju poreske prijave o godišnjem porezu na dohodak građana. Naime, godišnji porez na dohodak građana plaćaju fizička lica - rezidenti, uključujući i stranca - rezidenta, koji su u kalendarskoj godini ostvarili dohodak veći od trostrukog iznosa prosečne godišnje zarade po zaposlenom isplaćene u Republici u godini za koju se utvrđuje porez, prema podacima 
republičkog organa nadležnog za poslove statistike (član 87 ZOPNDHG). Obveznik godišnjeg poreza na dohodak građana dužan je da za ostvareni dohodak u godini za koju se vrši utvrđivanje poreza podnese poresku prijavu sa tačnim podacima nadležnom poreskom organu po isteku te godine, a najkasnije do 15. marta naredne godine (član 92 ZOPNDHG). Shodno tome, ukoliko fizičko lice do navedenog roga ne podnese propisno sastavljenu poresku prijavu, a ostvario je dohodak koji prevazilazi neporezivi iznos propisan članom 87. Zakona o porezu na dohodak građana, a iznos obaveze čije se plaćanje izbegava prelazi sto pedeset hiljada dinara, čini osnovni oblik krivičnog dela poreske utaje.

Utaja poreza na dodatu vrednost (PDV-a) predstavlja način izvršenja krivičnog dela poreske utaje koji u poslednjih nekoliko godina, tačnije od stupanja na snagu Zakona o porezu na dodatu vrednost, odnosno od 1. januara 2005 godine, postaje dominantan oblik poreske utaje. Dakle, s obzirom na uvođenje poreza na dodatu vrednost (PDV) u poreski sistem Republike Srbije, došlo je do pojave novih oblika izvršenja ovog krivičnog dela. Različiti su pojavni oblici utaje poreza na dodatu vrednosti. Jedan od načina izbegavanja plaćanja ovog poreza jeste nepodnošenje PDV prijave za poreski period za koji je obveznik po Zakono o PDV-u obavezan da obračinava PDV i preda poresku prijavu. Ovaj pojavni oblik utaje PDV-a podrazumeva ponašanje poreskog obveznika koje je u suprotnosti sa članom 37. Zakona o PDV-u, odnosno neizvršavanje obaveza koje su ovim članom utvrđene (nepodnošenje PDV prijave, neobračunavanje i neuplaćivanje PDV-a). Najčešće ovome prethodi nevođenje evidencije o ostvarenom prometu, odnosno neformiranja poslovne dokumentacije, u skladu sa članom 37, stav 3 Zakona o PDV-u [5, str. 118].Takođe, ovaj oblik utaje poreza vrši se davanjem lažnih podataka o činjenicama koje su od značaja za obračun, iskazivanje i plaćanje PDV-a, što se ogleda u neevidentiranju ukupno ostvarenog prometa u cilju umanjenja PDV-a, kao i korišćenju lažnih faktura. U prvom slučaju se u podnetoj poreskoj prijavi, uopšte ne prikazuje da je PDV obaveza koja je nastala po osnovu ostvarenog prometa dobara i usluga u odgovarajućem kalendarskom periodu, zato što se ostvareni promet uopšte i ne evidentira ili se prikaže samo deo ostvarenog prometa i na taj način delimično umanji stvarna poreska obaveza. U drugom slučaju, odnosno u slučaju korišćenja lažnih faktura, tj. lažnog fakturisanja, ogleda se u pravljenju lažnih ulaznih faktura sa iskazanim PDV-om, kako bi se neostvareno ostvarilo pravo na prethodni porez, a zatim se uopšte ne plati ili znatno umanji PDV obaveza. Ovi pojavni oblici uglavnom su vezani za poslovanje preko fiktivnih, odnosno tzv., „fantomskih firmi“. Naime, privredna društva koja su u sistemu PDV-a ispostavljaju lažne fakture na ime fiktivnih preduzeća, i na taj način obezbeđuju sebi povraćaj poreza, a da u stvarnosti nije ni došlo do prometa robe ili vršenja usluga.

Utaja akciza predstavlja način izvršenja krivičnog dela poreske utaje koji se ogleda u izbegavanju plaćanja akcize kao jedne forme poreskih dažbina. Radi se o malverzacijama koje su vezane za promet akciznih dobara, uglavnom naftnih derivata. Način izvršenja ovog oblika ogleda se u ilegalnoj nabavci, odnosno uvozu naftnih derivata i pravljenju lažnih faktura na ime fantomskih firmi u kojima se iskazuju akciza i PDV. Takva faktura se ne plaća što predstavlja neizmirivanje dažbina koje su u njoj iskazane. Ovako pribavljeni naftni derivati se zatim slobodno prodaju na legalnom tržištu, uz neosnovano korišćenje iskazanog PDV-a, kao 
prethodnog poreza i akciza, a po osnovu lažne fakture, čime se nanosi šteta državnom budžetu kako za neplaćenu akcizu, tako i za pripadajući PDV.

\section{ZAKLJUČAK}

Za svaku zemlju je od naročitog značaja da se realizacija poreskog sistema odvija uredno, blagovremeno i efikasno ostvarivanje. Izbegavanjem plaćanja poreske obaveze u potpunosti ili delimično ili neblagovremenim izvršavanjem utvrđenih obaveza po osnovu poreskih davanja i drugih davanja u vidu doprinosa i sl., krše se zakonski propisi i uzrokuju negativne posledice koje se manifestuju u nepotpunom ostvarivanju poreskih planova i bilansa, ugrožavanju budžeta države, a samim tim u znatnoj meri utiče i na zadovoljavanje opštih društvenih potreba i funkcionisanje državnih funkcija na raznim nivoima. Stoga svaka zemlja nastoji da ostvari efikasnu delatnost na polju blagovremenog otkrivanja, suzbijanja i sprečavanja krivičnog dela poreske utaje.

S obzirom na prirodu ovog krivičnog dela, tj. načine izvršenja kao i na načine rada, odnosno poslovanja subjekata privrednog poslovanja i drugih pravnih lica u okviru kojih se vrši krivično delo poreske utaje, svakako da bi vodeći način saznanja za postojanje ovog dela trebalo da budu prijave inspekcijskih organa. Međutim s obzirom na visok stepen korupcije pojedinih lica koji obavljaju poslove kontrole obračunavanja i plaćanja poreza, doprinosa i drugih dažbina broj prijava je izuzetno mali. S tim u vezi otkrivanje, suzbijanje i sprečavanje krivičnog dela poreske utaje predstavlja jedan veoma težak i složen zadatak.

Kako je utaja poreza uglavnom praćena falsifikovanjem određene dokumentacije, $u$ koju se unose neistiniti podaci o zakonito stečenim prihodima, obimu prometa, broju zaposlenih radnika, visini troškova i sl., to je najčešći način za saznanje o postojanju ovog dela uvid u poslovnu dokumentaciju i njeno upoređivanje sa primercima koji se nalaze kod nadležnih organa. $\mathrm{Na}$ ovaj način mogu se uvideti određene nepravilnosti u vezi sa obračunavanjem i prijavljivanjem poreza, doprinosa i drugih dažbina. Utvrđivanjem ovakvih nepravilnosti stiču se osnovi sumnje o postojanju krivičnog dela poreske utaje. Osim falsifikovanja poslovne dokumentacije, kako bi prikrili izvršenje ovog krivičnog dela učinioci pribegavaju delimičnom ili potpunom oštećenju ili uništavanju ove dokumentacije, pa bi stoga, nedostatak ove dokumentacije, predstavljao indiciju o izvršenju ovog krivičnog dela (npr., požar u kome je izgorela poslovna dokumentacija itd.).

Osim navedenih načina na postojanje ovog krivičnog dela može ukazivati i nesrazmerno trošenje novca. Naime, naglo bogaćenje, kupovina skupocenih stvari, kuća, stanova, vikendica, egzotična putovanja itd., mogu nam ukazati da je određena osoba ili subjekat privrednog poslovanja ostvarilo prihode u pozamašnom iznosu. S tim u vezi ukoliko je od strane te osobe ili privrednog društva prijavljen prihod, odnosno porez koji je u znatnoj disproporciji u odnosu na iznos koji je potrošen za kupovinu napred navedenih stvari stiču se osnovi sumnje da je izvršeno krivično delo poreske utaje.

Takođe, za postojanje ovog krivičnog dela organi unutrašnjih poslova mogu saznati putem javnog pogovaranja, zatim putem anonimnih i pseudonimnih prijava, iz 
sredstava javnog informisanja, korišćenjem prijateljskih i saradničkih veza, kao i neposrednim radom na terenu. Naime, u okviru pozorničke i patrolne delatnosti može se uočiti prodaja razne robe na pijacama, uličnim tezgama i trotoarima po znatno nižoj ceni od cene po kojoj se ista takva roba prodaje u trgovinskim radnjama. Ova činjenica može predstavljati indiciju da je to roba koja je nabavljena i stavljena $\mathrm{u}$ promet bez plaćanja poreza. Osim organa unutrašnjih poslova do saznanja za postojanje ovog krivičnog dela mogu doći i drugi organi u sklopu svoje delatnosti, kao što su subjekti platnog prometa, poreska uprava, inspekcijski i carinski organi. Posebnu pažnju pripadnici ovih organa trebalo bi da posvete psihološkim tragovima koji nastaju kao posledica psihološkog dejstva krivičnog dela na učinioca. Ovi tragovi ispoljavaju se u specifičnom ponašanju izvršioca nakon izvršenja krivičnog dela. Radi se o ponašanju koje se karakteriše drhtanjem glasa, crvenilom, znojenjem, uznemirenošu, lomljenjem prstiju i sl. Ovakvo ponašanje pripadnicima inspekcijskih, carinskih i drugih organa može da ukaže na postojanje krivičnog dela poreske utaje. Stoga je za otkrivanje, sprečavanje i suzbijanje ovog krivičnog dela neophodna koordinacija i saradnja policije sa ovim organima. Osim toga, krivično delo poreske utaje uglavnom vrše poslovni ljudi, što ovaj vid kriminalnog ispoljavanja svrstava u kriminalitet „belog okovratnika“.

Po sticanju osnova sumnje o postojanju krivičnog dela poreske utaje, neophodno je preduzeti određene kriminalističko taktičke mere i radnje, poput osmatranja, praćenja i sl, kako bi se prikupile određene informacije u vezi sa vremenom, načinom izvršenja, visinom utajenog poreza, ličnošću osumnjičenog. Na osnovu prikupljenih informacija postavljaju se određene verzije i sačinjava plan operativne delatnosti, s ciljem da se prikupe relevantni materijalni i lični dokazi, kako bi se početni nivo sumnje podigao na stepen osnovane sumnje.

Što se tiče prevencije ovog krivičnog dela, ona se ogleda u otklanjanju uzroka i uslova koji pogoduju njegovom izvršenju, npr. češće kontrole privrednih društava od strane poreskih inspektora, zatim pooštravanje kaznene politike u oblasti javnih prihoda, kao i permanentnim razmatranjem i analizom načina izbegavanja poreskih obaveza, kako bi se blagovremeno predvideli eventualni novi pojavni oblici, koji se uglavnom javljaju prilikom promene poreskih propisa.

\section{BIBLIOGRAFIJA}

1.Čejović B., Kulić M. (2011) Krivično pravo, Beograd: Službeni glasnik.

2. Milošević, G. (2005) Poreska krivična dela, Časopis: Bezbednost 4/`05, str. 616-631, Beograd: MUP Republike Srbije.

3. Milošević, G. (2002) Krivično delo izbegavanja plaćanja poreza, Časopis: Bezbednost 6/ 02, str. 910-925, Beograd: MUP Republike Srbije.

4. Kulić, M. (1999) Poreska utaja i krijumčarenje, Beograd.

5. Simonović D. (2010) Krivična dela u srpskoj legislativi, Beograd: Službeni glasnik.

6. Vuković, M. (2009) Poreska utaja u policijskoj i sudskoj praksi, Beograd: Službeni glasnik.

7. Krivični zakonik "Službeni glasnik RS", br. 85/2005, 88/2005, 107/2005, 72/2009, 111/2009.

8. Zakon o poreskom postupku i poreskoj administraciji "Sl. glasnik RS", br. 80/2002, 84/2002 - ispr., 23/2003 - ispr., 70/2003, 55/2004, 61/2005, 85/2005 - dr. zakon, 62/2006 - 
dr. zakon, 63/2006 - ispr. dr. zakona, 61/2007, 20/2009, 72/2009 - dr. zakon, 53/2010, 101/2011, 2/2012 - ispr., 93/2012.

9. Zakon o porezu na dohodak građana „Službeni glasnik RS“, br. 24/01, 80/02, 80/02 - dr zakon, 135/04, 62/06, 65/06 -ispr., 31/09, 44/09, 18/10, 50/11, 91/11 - odluka US, 7/12 usklađeni din. izn., 93/12, 114/12 - odluka US i 8/13 - usklađeni din. izn.

10.Zakon o porezu na dodatu vrednosti "Službeni glasnik RS", br. 84/2004, 86/2004, 61/2005, 61/2007, 93/2012.

\section{RESUME}

For each country, it is of particular importance that the realization of the tax system is proper, timely and efficient. Evasion of the tax liability in full or in part or untimely performance of the obligations is a violation of law and causes negative effects that are manifested in incomplete implementation of tax planning and income, threats to the state budget, and thus significantly affect the overall satisfaction of social needs and the functioning of government functions at various levels. Therefore, every country is trying to achieve an efficient activity in the field of early detection, eradication and prevention of the crime of tax evasion. Given the nature of the crime, i.e. the manner of execution, the leading way to gain knowledge of the existence of tax evasion should be the application of inspection. But given the high level of corruption of certain persons who perform control activities the efficiency of this instrument is very low. In this regard, detection, control and prevention of the crime of tax evasion is a very difficult and complex task.

As tax evasion is generally accompanied with forging certain documents, which contain inaccurate information about the legally acquired income, trading volume, number of employees, the cost etc., the most common way of finding out about the existence of tax evasion is analysing business documents and its comparison with examples in the hands of authorities. In this way, it can be seen that there are certain irregularities in the calculation and reporting of taxes, contributions and other duties. Determination of such irregularities are acquired based on suspicion of the crime of tax evasion. In addition to falsifying business records in order to conceal the commission of this crime, perpetrators resort to partial or total damage or destruction of records, and therefore, lack of documentation, is an indication of existence of the offense (e.g. a fire which burnt business documents, etc.).

By obtaining reasonable doubt about the existence of the crime of tax evasion, it is necessary to take certain measures and tactical activities, such as surveillance, monitoring, etc., in order to gather specific information as to the time, manner of execution, the amount of tax evaded, the personality of the suspect. Based on the information gathered to set a specific version of the operating plan consists of activities in order to collect relevant material and personal evidence to the initial level of suspicion raised to the level of reasonable suspicion. With regard to prevention of this crime, it is reflected in the elimination of the causes and conditions that are favourable to its execution, for example a greater degree of control of companies by tax inspectors, tightening of penal policy in the field of taxation, as well as permanent review and analysis of ways of avoiding taxes, in order to timely anticipate possible new forms, which generally occur when there are changes in tax regulations. 